\title{
Molecular and serological detection of Ehrlichia canis in naturally exposed dogs in Iran: an analysis on associated risk factors
}

\author{
Detecção molecular e sorológica de Ehrlichia canis em cães naturalmente expostos no Irã: \\ uma análise dos fatores de risco associados \\ Nadi Maazi ${ }^{1}$; Abdolali Malmasi ${ }^{1 *}$; Parviz Shayan² ${ }^{2}$ Seyed Mahdi Nassiri ${ }^{3}$; \\ Taghi Zahraei Salehi ${ }^{4}$; Mojdeh Sharifian Fard ${ }^{5}$

\begin{abstract}
${ }^{1}$ Department of Internal Medicine, Faculty of Veterinary Medicine, University of Tehran, Tehran, Iran
${ }^{2}$ Center for Ticks and Tick-borne Diseases, Faculty of Veterinary Medicine, University of Tehran, Tehran, Iran

${ }^{3}$ Department of Pathobiology, Faculty of Veterinary Medicine, University of Tehran, Tehran, Iran

${ }^{4}$ Department of Microbiology and Immunology, Faculty of Veterinary Medicine, University of Tehran, Tehran, Iran

${ }^{5}$ Department of Pathology, Bacteriology and Avian Diseases, Faculty of Veterinary Medicine, Ghent University, Belgium
\end{abstract}

Received June 18, 2013

Accepted December 5, 2013

\begin{abstract}
The general aim of this study, which was conducted for the first time in Iran, was to evaluate the seroprevalence and geographical distribution of Ehrlichia canis in a dog population in Iran, followed by molecular confirmation using PCR and sequencing. Blood samples were collected from 240 dogs in different areas of Alborz and Tehran Provinces and initially analyzed using the immunofluorescent antibody (IFA) test to detect anti-Ehrlichia canis IgG antibodies. Subsequently, nested PCR was performed based on a fragment of the 16S rRNA gene of $E$. canis on serologically positive samples. The results showed that $40 / 240$ dogs (16.6\%) presented anti-Ehrlichia canis IgG antibodies and that nine of the blood samples from the 40 seropositive dogs $(22.5 \%)$ contained E. canis DNA, which was confirmed by sequencing. The seroprevalence of $E$. canis tended to be higher in purebred, one to three-year-old male dogs living in the Plain zone, in rural areas; however, this difference was not statistically significant.
\end{abstract}

Keywords: Ehrlichiosis, Ehrlichia canis, IFA, nested PCR, dogs, Iran.

\section{Resumo}

O objetivo geral deste estudo, que foi feito pela primeira vez no Irã, foi avaliar a soroprevalência e distribuição geográfica de Ehrlichia canis em população de cães no Irâ, seguida da confirmação molecular por meio de PCR seguida de sequenciamento. Amostras de sangue de 240 cáes de diferentes áreas das Províncias de Alborz e Teeră foram coletadas e, inicialmente, analisadas pelo Reação de Imunofluorescência (IFA) para detecção de anticorpos IgG anti-Ehrlichia canis Subsequentemente, uma reação do tipo nested PCR baseada em um fragmento do gene $16 \mathrm{~S}$ rRNA de E. canis foi realizada nas amostras sorologicamente positivas. Os resultados mostraram que 40/240 cáes (16,6\%) apresentaram anticorpos IgG anti- Ehrlichia canis e nove (22,5\%) das amostras de sangue dos 40 cães soropositivos continham DNA de E. canis, confirmado por sequenciamento. A soroprevalência de E. canis, embora não estatisticamente significativa, mostrou uma tendência em se apresentar maior em cães machos com 1-3 anos, de raça pura, que vivem em zonas planas e áreas rurais.

Palavras-chave: Erliquiose, Ehrlichia canis, IFA, nested PCR, cães, Irã. 


\section{Introduction}

Ehrlichia canis, a pleomorphic Gram-negative obligate intracellular bacterium, is classified in the family Anaplasmataceae (HUXSOLL et al., 1970) and is primarily transmitted by the brown dog tick Rhipicephalus sanguineus, with worldwide distribution (GROVES et al., 1975).

This organism presents tropism for mononuclear leukocytes and causes canine monocytic ehrlichiosis (CME), which is an important emerging canine disease. Although CME is a cosmopolitan tickborne infection, it has been predominantly reported in tropical and subtropical regions, where associated vector ticks have highly prevalent geographical distribution (NEER et al., 2002).

The emergence of several strains of $E$. canis has led to use of faster and more accurate diagnostic techniques such as serological tests, e.g. the immunofluorescent antibody (IFA) test, and molecular assays, e.g. the polymerase chain reaction (PCR). Consequently, several strains of E. canis such as the Thai, Turkish, Venezuelan and Greek strains have been detected using PCR in different geographical regions. The seroprevalence of $E$. canis among dogs in the Middle East was reported to be $21 \%$ in Turkey (BATMAZ et al., 2001) and 30\% in Israel (BANETH et al., 1996). Recent surveys in the cities of Kerman and Ahvaz in Iran revealed that $14.63 \%$ and $9.6 \%$ of dogs were seropositive for $E$. canis respectively (AKHTARDANESH et al., 2010; AVIZEH et al., 2010).

The purpose of the present preliminary study, which was conducted for the first time in Iran, was to evaluate the seroprevalence and geographical distribution of $E$. canis infection and the risk factors associated with this, along with molecular detection and identification of its 16 S rRNA partial sequence in dog populations in Alborz and Tehran provinces.

\section{Materials and Methods}

\section{Study site}

This study was carried out in Alborz and Tehran provinces, which are located in the north of the central plateau of Iran (Figure 1). They are adjacent and lie between longitudes $50^{\circ} 10^{\prime}$ and $53^{\circ} 10^{\prime} \mathrm{E}$ and latitudes $34^{\circ} 52^{\prime}$ and $36^{\circ} 21^{\prime} \mathrm{N}$, at altitudes ranging from 790 to 5678 meters above sea level. The hottest months of the year are from mid-July to mid-September $\left(30-35^{\circ} \mathrm{C}\right)$ and the coldest months are experienced around December-January $\left(-15\right.$ to $\left.+1{ }^{\circ} \mathrm{C}\right)$. The average annual rainfall is approximately $400 \mathrm{~mm}$. Both of these provinces consist of two different geographical zones: Foothill and Plain. The Foothill zone consists of Shemiran, Damavand and northern parts of Karaj and Savojbolagh counties, at altitudes ranging from 1500 to 2500 meters above sea level. The climate of this zone is cold and semi-humid. The Plain zone consists of Mallard, Shahriar, Eslamshahr, Robat Karim, Rey, Varamin, Nazarabad and other parts of Karaj and Savojbolagh counties, which have altitudes ranging from 900 to 1500 meters above sea level, with a warm and dry climate.

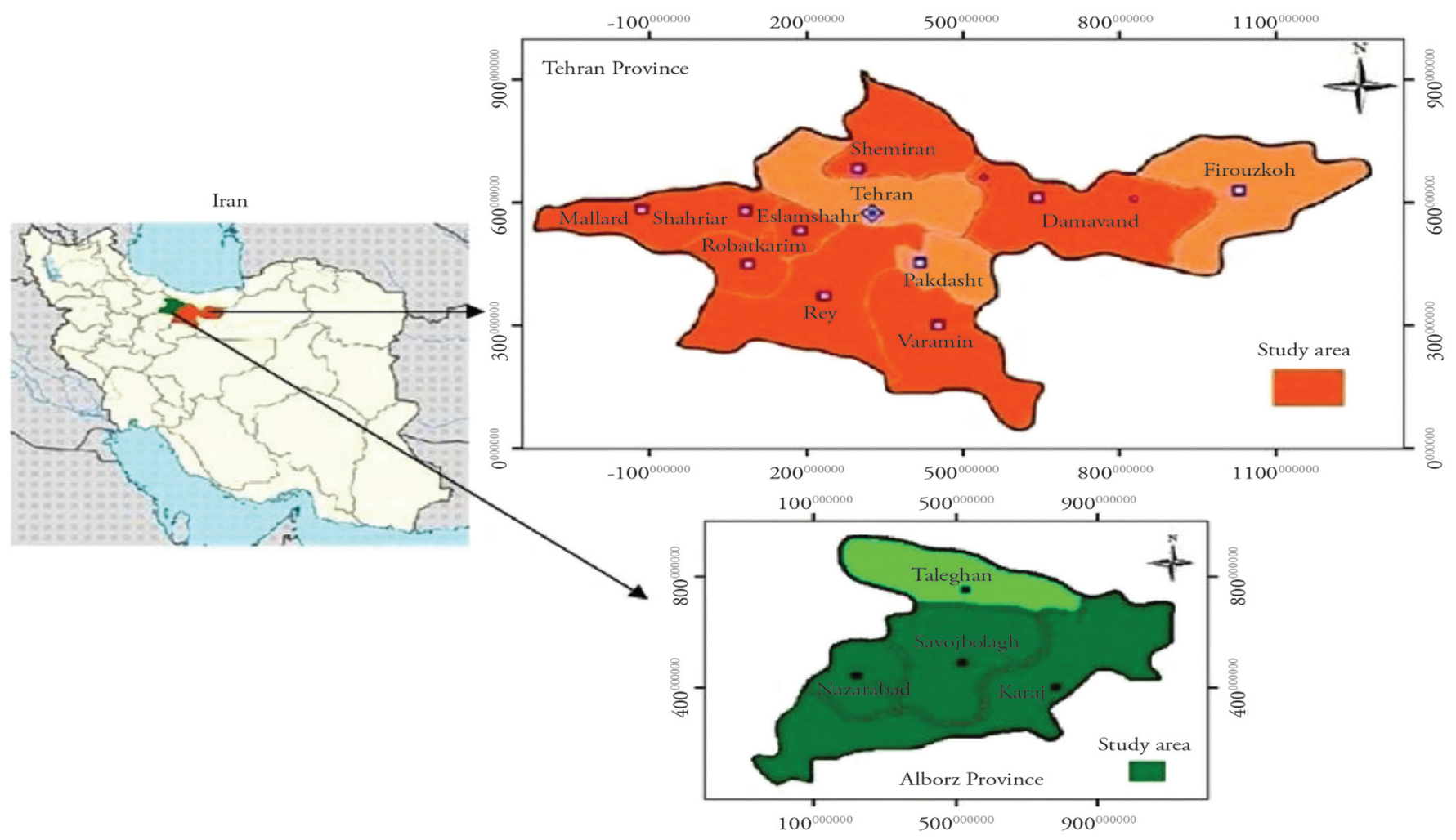

Figure 1. Map of Iran showing the two provinces and eleven localities (Damavand, Eslamshahr, Rey, Robatkarim, Shahriar, Shemiran, Mallard, Varamin, Savojbolagh, Karaj, Nazar Abad) where this survey was conducted. 


\section{Sample collection}

In this study, 240 dogs living in two zones (Foothill and Plain) of Alborz and Tehran provinces were selected randomly. Information on each dog regarding age, breed, sex, geographical zone (Foothill or Plane), type of residential area (urban or rural), tick presence, history of tick infestation and anti-ectoparasite treatment was recorded through questionnaires. Ticks were recovered manually from dogs during blood collection and were stored in $70 \%$ ethanol for morphological identification. Two blood samples were taken from the cephalic or jugular vein of each dog by means of puncture. One sample was collected in an anticoagulant-free tube; this was then allowed to clot and was finally centrifuged $(800 \times \mathrm{g}$ for $30 \mathrm{~min})$ to separate the serum. Serum was stored at $-20{ }^{\circ} \mathrm{C}$ until serological testing. Another sample was collected in tube containing EDTA as the anticoagulant, for hematological and cytological analysis and DNA extraction. Complete blood counts were performed using an automated hematological analyzer. Buffy coat films were then prepared, stained with Wright-Giemsa, and examined microscopically to detect $E$. canis morulae as previously described (RODRIGUEZ-VIVAS et al., 2005). The samples were kept frozen at $-20{ }^{\circ} \mathrm{C}$ until DNA extraction.

\section{Serological testing}

Serum samples were screened for detection of IgG antibodies against $E$. canis using a micro-immunofluorescent assay (IgG MIF kit, Fuller Laboratories, Fullerton, CA, USA). Serum samples were diluted to 1:80 in phosphate-buffered saline (PBS) (pH: 7.2) and the procedure was performed as described by the provider. Positive and negative controls were included in the kit.

\section{DNA extraction}

DNA was extracted from $150 \mu \mathrm{L}$ of the whole blood of serologically positive samples by using a DNA isolation kit (MBST Inc., Tehran, Iran), in accordance with the manufacturer's instructions. The extracted DNA was eluted in $100 \mu \mathrm{L}$ of elution buffer and stored at $-20{ }^{\circ} \mathrm{C}$.

\section{PCR amplification}

Nested PCR was performed to detect $E$. canis DNA. In the outer reaction, a portion of the $16 \mathrm{~S}$ rRNA of Ehrlichia species was amplified by using ECC (5-AGAACGAACGCTGGCGGCAAGC-3) and ECB (5-CGTATTACCGCGGCTGCTGGCA-3) primers (DAWSON et al., 1994). The PCR amplification was performed in a $50 \mu \mathrm{L}$ reaction mixture containing $5 \mu \mathrm{L}$ of extracted DNA template, $0.2 \mathrm{mM}$ of dNTPs, $1.5 \mathrm{mM}$ of $\mathrm{MgCl}_{2}, 0.4 \mu \mathrm{M}$ of each primer, 1x of Taq buffer and 2U of Taq polymerase (Cinnagen, Iran) under the conditions previously described (DAWSON et al., 1994) with some modifications: initial denaturation at $94{ }^{\circ} \mathrm{C}$ for $3 \mathrm{~min}$, then 38 cycles at $94^{\circ} \mathrm{C}$ for $45 \mathrm{~s}, 66^{\circ} \mathrm{C}$ for $45 \mathrm{~s}$, $72{ }^{\circ} \mathrm{C}$ for $45 \mathrm{~s}$ and final extension at $72{ }^{\circ} \mathrm{C}$ for $10 \mathrm{~min}$. The nested reactions were performed using $1 \mu \mathrm{L}$ of the outside reaction as the template, with the species-specific primers ECF
(5-CCGAGGGGGAAAGATTTATCGCTAT-3) and ECR (5-AAGGCCTTCTTCACTCACGCGG-3) for E. canis, under the same conditions as above but with 30 cycles of PCR amplification and with an annealing temperature of $60{ }^{\circ} \mathrm{C}$ for 45 s. A $224 \mathrm{bp}$ sequence of the $16 \mathrm{~S}$ rRNA gene was generated. The speciesspecific primers were designed from the hypervariable region of the 16S rRNA gene by means of a primer design program (National Center for Biotechnology Information). E. canis DNA (kindly supplied by Kawsar Tech Exploration Co., Tehran, Iran) and distilled water were included as positive and negative controls, respectively. The PCR products were analyzed using $1.5 \%$ agarose gel electrophoresis, stained with ethidium bromide and photographed. To prevent contamination, DNA extraction and PCR were performed in separate areas.

\section{DNA sequencing and BLAST analysis}

The nested PCR products were purified using the PCR purification kit (MBST Inc., Tehran, Iran) in accordance with the manufacturer's instructions and were sequenced with the same primers used in the nested PCR by means of an automated DNA sequencer (ABI 3130, Applied Biosystems). The DNA sequences obtained were aligned using the software programs BioEdit (HALL, 1999) and ClustalW (THOMPSON et al., 1994) and were blasted in GenBank (http://www.ncbi.nlm.nih.gov/BLAST).

\section{Statistical analysis}

The seroprevalence of $E$. canis with regard to risk factors such as geographical zone (Foothill or Plain), gender (female or male), age (1-3, 3-5 or more than 5 years old), breed (purebred or mongrel), tick infestation (observed or not observed) and animal residence area (urban or rural) was analyzed by means of the Phi and Cramer's V coefficients and the T-test and Pearson correlation statistical tests at the significant levels of $\mathrm{p}<0.05$ and $\mathrm{p}<0.01$.

\section{Results}

The population of this study consisted of 154 males (64.16\%) and 86 females (35.84\%), with ages ranging from six months to eleven years (mean 2.95 years) (Table 1). Fifty-three of these animals were purebred and 187 were mongrels (Table 1). Tick infestation was observed in 82 dogs (34.2\%) at the time of sampling, although all of the dogs had histories of tick infestation and most of them $(86 \%)$ had never received any previous anti-ectoparasite treatment (Table 1). The ticks recovered were identified in accordance with the keys provided by Wall and Shearer (2001) as $R$. sanguineus (91\%), R. bursa (6\%) and $R$. turanicus (3\%). No mixed infestations with two or more tick species were detected.

In the serological analysis, $\mathrm{IgG}$ antibodies against $E$. canis were detected in 40 dogs (16.6\%), of which 28 were male and 12 were female. The results from IFA and PCR are summarized in Table 2 based on the geographical zones, sex, breed, age, animal residence area and tick infestation. The majority of the seropositive dogs were male and lived in the Plain zone, in rural areas. Furthermore, the 
highest prevalence was seen in purebred dogs and in the age group of $1-3$ years. Sixteen dogs (40\%) among the seropositive animals had tick infestations at the time of blood sampling. However, no significant differences among these results were found.

In cytological examinations, inclusion bodies were seen in five dogs $(2.1 \%)$, but only one of them was positive for $E$. canis using the IFA and PCR assays. The seropositive dogs had an average count of 214,000 platelets/ $\mu \mathrm{l}, 5.48$ red blood cells (RBC) $\times 10^{6} / \mu \mathrm{l}$ and packed cell volume (PCV) of $32.16 \%$, whereas these value were $347,500 / \mu \mathrm{l}, 7.15 \times 10^{6} / \mu \mathrm{l}$ and $42.43 \%$ in the seronegative dogs. The mean PCV percentage among the IFApositive purebred dogs was $37.73 \%$ while it was $30.53 \%$ among the mongrels. Furthermore, the mean RBC count and PCV of the IFA-positive dogs that lived in rural areas were $5.98 \times 10^{6} / \mu \mathrm{l}$ and $35.00 \%$, in contrast with $4.85 \times 10^{6} / \mu \mathrm{l}$ and $28.67 \%$ in urban regions, respectively (Table 3 ). Thrombocytopenia (platelet count $<200,000 / \mu \mathrm{l})$ and anemia (RBC count $\left.<5.5 \times 10^{6} / \mu \mathrm{l}, \mathrm{PCV}<35 \%\right)$ were observed in $60(25 \%)$ and $50(20.8 \%)$ of the dogs. Among

Table 1. Characteristics of the population studied $(n=240)$ in Alborz and Tehran provinces, Iran.

\begin{tabular}{llcc}
\hline & & N. dogs & $\mathbf{( \% )}$ \\
\hline Geographical zone & Foothill & 72 & 30 \\
& Plain & 168 & 70 \\
\multirow{5}{*}{ Breed } & Male & 154 & 64.2 \\
& Female & 86 & 35.8 \\
Age group & Purebred & 53 & 22.1 \\
& Mongrel & 187 & 77.9 \\
\multirow{5}{*}{ Residence area } & 1-3 years & 131 & 54.6 \\
& 3-5 years & 70 & 29.2 \\
Tick infestation & More than 5 years & 39 & 16.3 \\
& Urban & 135 & 56.3 \\
Total & Rural & 105 & 43.8 \\
& Yes & 82 & 34.2 \\
& No & 158 & 65.8 \\
& & 240 & 100 \\
\hline
\end{tabular}

the 40 seropositive animals, 26 (65\%) had thrombocytopenia and $29(72.5 \%)$ had anemia.

A total of 40 seropositive dogs were screened using the nested PCR technique and, among them, nine animals (22.5\%) were positive for E. canis. Of those animals, six were males and three had tick infestation. Sequence analysis on these amplicon sequences showed high similarity (99-100\%) with the 16S rRNA gene sequences of $E$. canis strains that are available in the GenBank database. The $16 \mathrm{~S}$ rRNA sequences from this study were deposited in the GenBank database under accession numbers JX556420 and JX556421 for E. canis Irani1 and Irani2, respectively.

\section{Discussion}

The results from this study demonstrated that the seroprevalence of E. canis in dogs in the Alborz and Tehran provinces of Iran is $16.6 \%$ using the IFA test, which is in consistent with the findings in Kerman (14.63\%; AKHTARDANESH et al., 2010) but significantly higher than the findings in Ahvaz (9.6\%; AVIZEH et al., 2010). The higher seroprevalence found in Turkey (21\%) and Israel (30\%) (BATMAZ et al., 2001; BANETH et al., 1996, respectively) might be associated with different climatic conditions, the severity of tick infestation and use of preventive or therapeutic anti-ectoparasite applications.

In this study, $22.5 \%$ of the seropositive dogs had E. canis DNA. These results revealed differences between the IFA and PCR findings, i.e. $77.5 \%$ of the seropositive dogs were PCR-negative, possibly due to previous exposure, cross-reactivity between Ehrlichia and Anaplasma species (WANER et al., 2001) or detection of levels of Ehrlichia below the limits of PCR tracing, particularly during the chronic phase of the disease (AGUIRRE et al., 2004). Dawson et al. (1996) and Murphy et al. (1998) observed similar results among dogs in Virginia and Oklahoma, USA, respectively.

Analysis on variables such as sex, breed and age did not show any significant differences $(\mathrm{p}<0.05)$ among them, although the prevalence was higher in male dogs $(18.2 \%)$, which is in agreement with Rodriguez-Vivas et al. (2005) and Solano-Gallego et al. (2006)

Table 2. Analysis on risk factors among positive and negative dogs tested using IFA and PCR.

\begin{tabular}{|c|c|c|c|c|c|}
\hline \multirow{2}{*}{\multicolumn{2}{|c|}{ Variables* }} & \multicolumn{2}{|c|}{ IFA } & \multicolumn{2}{|c|}{ PCR } \\
\hline & & \multirow{2}{*}{$\frac{\text { N. positive (\%) }}{8(11.1)}$} & \multirow{2}{*}{$\begin{array}{c}\text { N. tested } \\
72\end{array}$} & \multirow{2}{*}{$\frac{\text { N. positive (\%) }}{0(0)}$} & \multirow{2}{*}{$\frac{\text { N. tested }}{8}$} \\
\hline Geographical zone & Foothill & & & & \\
\hline & Plain & $32(19)$ & 168 & $9(28.1)$ & 32 \\
\hline \multirow[t]{2}{*}{ Sex } & Female & $12(14)$ & 86 & $3(25)$ & 12 \\
\hline & Male & $28(18.2)$ & 154 & $6(21.4)$ & 28 \\
\hline \multirow{2}{*}{ Breed } & Purebred & $9(17)$ & 53 & $2(22.2)$ & 9 \\
\hline & Mongrel & $31(16.6)$ & 187 & 7 (22.6) & 31 \\
\hline \multirow[t]{3}{*}{ Age Group } & $1-3$ years & $24(18.3)$ & 131 & $7(29.2)$ & 24 \\
\hline & $3-5$ years & $11(15.7)$ & 70 & $2(18.2)$ & 11 \\
\hline & More than 5 years & $5(12.8)$ & 39 & $0(0)$ & 5 \\
\hline \multirow[t]{2}{*}{ Residence area } & Urban & $18(13.3)$ & 135 & $4(22.2)$ & 18 \\
\hline & Rural & $22(21)$ & 105 & $5(22.7)$ & 22 \\
\hline \multirow[t]{2}{*}{ Tick infestation } & Yes & $16(19.5)$ & 82 & $3(18.8)$ & 16 \\
\hline & No & $24(15.2)$ & 158 & $6(25)$ & 24 \\
\hline Total & & 40 & 240 & 9 & 40 \\
\hline
\end{tabular}

* There was no significant difference in comparison of risk factors among positive and negative dogs according to the Phi and Cramer's V coefficients. N - Number; $\%$ - percentage. 
but not with Batmaz et al. (2001). Furthermore, the frequency of seropositivity was higher in dogs aged $1-3$ years $(18.3 \%)$ than in other age groups. Also, dogs with tick infestation were at greater risk (odds ratio $=1.2$ ) of seropositivity for canine ehrlichiosis, which is in agreement with Trapp et al. (2006) and Costa et al. (2007).

In agreement with previous reports (BANETH et al., 1996; NEER et al., 2002), hematological findings such as thrombocytopenia and anemia were significantly more frequent in seropositive dogs than in seronegative dogs $(\mathrm{P}<0.05)$. Thrombocytopenia that is observed in the acute, chronic or subclinical stage of the disease may be due to destruction and consumption of platelets, increased hepatic or splenic platelet sequestration, decreased platelet production following bone marrow hypoplasia (WOODY; HOSKINS, 1991) and production of antiplatelet antibodies (GAUNT et al., 2010). Several mechanisms such as the effects of the mononuclear phagocytic system, cell

Table 3. Comparison of mean age, platelet, RBC and PCV values of the dogs studied.

\begin{tabular}{|c|c|c|c|c|}
\hline \multirow{2}{*}{ Variable } & \multicolumn{2}{|c|}{ Breed } & \multirow{2}{*}{ T-value } & \multirow{2}{*}{ Sig. } \\
\hline & Mongrel & Purebred & & \\
\hline Age $(\mathrm{Y})$ & 2.52 & 3.61 & -1.69 & 0.09 \\
\hline Platelet $(103 / \mu \mathrm{l})$ & 207.19 & 237.11 & -0.49 & 0.62 \\
\hline $\operatorname{RBC}(106 / \mu \mathrm{l})$ & 5.20 & 6.43 & -1.86 & 0.07 \\
\hline \multirow[t]{3}{*}{ PCV $(\%)$} & 30.53 & 37.73 & -1.99 & $0.05^{*}$ \\
\hline & \multicolumn{2}{|c|}{ Sex } & & \\
\hline & Male & Female & & \\
\hline Age (Y) & 2.67 & 3.00 & -0.54 & 0.58 \\
\hline Platelet $(103 / \mu \mathrm{l})$ & 209.82 & 223.50 & -0.24 & 0.80 \\
\hline $\operatorname{RBC}(106 / \mu \mathrm{l})$ & 5.55 & 5.29 & 0.42 & 0.67 \\
\hline \multirow[t]{3}{*}{ PCV (\%) } & 32.93 & 30.34 & 0.75 & 0.45 \\
\hline & \multicolumn{2}{|c|}{ Residence } & & \\
\hline & Rural & Urban & & \\
\hline Age $(\mathrm{Y})$ & 3.13 & 2.32 & 1.50 & 0.14 \\
\hline Platelet $(103 / \mu \mathrm{l})$ & 193.68 & 238.66 & -0.88 & 0.38 \\
\hline $\operatorname{RBC}(106 / \mu \mathrm{l})$ & 5.98 & 4.85 & 2.05 & $0.04^{*}$ \\
\hline \multirow[t]{3}{*}{ PCV $(\%)$} & 35.00 & 28.67 & 2.10 & $0.04^{*}$ \\
\hline & \multicolumn{2}{|c|}{ Tick infestation } & & \\
\hline & No & Yes & & \\
\hline Age $(\mathrm{Y})$ & 3.14 & 2.20 & 1.72 & 0.09 \\
\hline Platelet $(103 / \mu \mathrm{l})$ & 202.08 & 231.68 & -0.57 & 0.57 \\
\hline $\operatorname{RBC}(106 / \mu \mathrm{l})$ & 5.39 & 5.60 & -0.36 & 0.71 \\
\hline \multirow[t]{3}{*}{ PCV (\%) } & 31.89 & 32.55 & -0.20 & 0.83 \\
\hline & \multicolumn{2}{|c|}{ PCR } & & \\
\hline & Negative & Positive & & \\
\hline Age (Y) & 2.90 & 2.42 & -0.71 & 0.47 \\
\hline Platelet $(103 / \mu \mathrm{l})$ & 232.76 & 169.00 & -1.05 & 0.29 \\
\hline $\operatorname{RBC}(106 / \mu \mathrm{l})$ & 5.57 & 5.17 & -0.57 & 0.56 \\
\hline \multirow[t]{3}{*}{ PCV (\%) } & 32.73 & 30.67 & -0.72 & 0.59 \\
\hline & \multicolumn{2}{|c|}{ IFA } & & \\
\hline & Negative & Positive & & \\
\hline Age (Y) & 2.98 & 2.77 & -0.72 & 0.46 \\
\hline Platelet $(103 / \mu \mathrm{l})$ & 347.51 & 213.92 & -4.34 & $0.00^{* *}$ \\
\hline $\operatorname{RBC}(106 / \mu \mathrm{l})$ & 7.14 & 5.47 & -7.50 & $0.00^{* *}$ \\
\hline PCV (\%) & 42.42 & 32.15 & -8.43 & $0.00^{* *}$ \\
\hline
\end{tabular}

lysis mediated by the complement system and suppression of erythropoiesis at the bone marrow (CARLOS et al., 2011) may lead to anemia.

As shown in Table 3, the mean PCV among IFA positive samples was significantly higher in the purebred dogs than in the mongrels $(\mathrm{P}<0.05)$. Furthermore, the IFA-positive dogs that lived in rural areas had significantly higher RBC counts and PCV $(\mathrm{P}<0.05)$, compared with those in urban regions. Based on these results, it can be concluded that dog breed and residence area may affect the severity of anemia in seropositive animals. The Pearson coefficient matrix between the main variables showed some associations between the factors (Table 4), among which, RBC and PCV had significant positive correlations with age $\left(\mathrm{R}^{2}=0.33\right.$ and 0.31 , respectively; $\mathrm{P}<0.05)$. In other words, for older dogs, the RBC and PCV values were also greater. Because of the limited number of confirmed positive samples, this finding and also the positive effect of age on RBC and PCV values, as found in this statistical analysis, need further studies.

The seroprevalence was higher in dogs living in the Plain zone and in rural areas than it was in the Foothill zone and in urban areas, which was also reported by Lim et al. (2010) in Korea and Costa et al. (2007) in Brazil. This may be explained by a number of factors, such as suitable environmental conditions for tick survival (for example, warmer temperatures that lead to higher tick infestation rates) and the lack of ectoparasite control programs in rural areas and in the Plain zone.

The influence of climatic conditions on the dynamics of tick populations has also been shown (SONENSHINE, 1993; RANDOLPH, 2008). In cold climates $\left(<17^{\circ} \mathrm{C}\right)$, the number of tick generations produced within a year becomes smaller because of delay in oviposition, with interference in egg eclosion and an increased parasitic phase (SONENSHINE, 1993). In the present study, the Plain zone had an optimal temperature for development of ticks, thus showing a higher number of infested dogs (45.8\%) with higher seroprevalence (19\%), while the Foothill zone, with cold temperatures, had a lower percentage of infested animals (6.9\%) with lower seroprevalence (11.1\%). Thus, dogs living in the Plain zone had a higher risk of exposure to $E$. canis and higher seroprevalence $(\mathrm{p}<0.05)$, in comparison with dogs living in the Foothill zone.

Apart from climatic conditions, certain epidemiological factors such as vector distribution, animal behavior, age of the population studied (RODRIGUEZ-VIVAS et al., 2005; TRAPP et al., 2006; LIM et al., 2010), management practices and habitat where the animals live (SAINZ et al., 1995) may affect the prevalence of canine ehrlichiosis. The prevalence of $E$. canis in dogs that lived in rural areas was $21 \%$ in this study, which was much higher than

Table 4. Analysis on correlation between age, platelet, RBC and PCV values of the population sampled (Pearson coefficient).

\begin{tabular}{lccll}
\hline \multicolumn{1}{c}{ Variable } & Age & Platelet & RBC & PCV \\
\hline Age & 1.00 & & & \\
Platelet & -0.13 & 1.00 & & \\
RBC & $0.33^{*}$ & 0.07 & 1.00 & \\
PCV & $0.31^{*}$ & 0.03 & $0.97^{* *}$ & 1.00 \\
\hline
\end{tabular}

$\left({ }^{*} \mathrm{R} 2=0.33\right.$ and $\left.0.31 ;{ }^{* *} \mathrm{P}<0.05\right)$ 
among urban animals $(\mathrm{p}<0.05)$. The results suggest that dogs living in rural areas are more exposed to tick vectors than those living in urban areas, which may be related to better sanitary conditions with regular anti-ectoparasite treatments among urban dogs and poor living conditions among rural dogs.

The nucleotide sequences of the 16S rRNA partial gene from all the nine positive dogs were identical. Eight of them were quite similar [E. canis Irani1: JX556420] and the other one had slight differences [E. canis Irani2: JX556421]. These sequences were $100 \%$ identical to E. canis strains from dogs in Brazil [EF195134, EU376116], Venezuela [AF373614], India [JN967645], Japan [AF308455], Taiwan [GU810149], USA [M73221, M73226], and had 99\% similarity with strains reported from Peru [DQ915970], China [AF156785], Tunisia [EU781695], Italy [GQ857078] and Spain [AY394465]. Further molecular investigations and phylogenetic analyses are needed to better understand the genetic diversity and affinity of $E$. canis from dogs in Iran, compared with strains reported from other geographical areas.

\section{Conclusions}

The present study amplified and sequenced part of the $16 \mathrm{~S}$ rRNA gene of E. canis, and conducted molecular confirmation of E. canis for the first time in Iran. The risk of exposure to E. canis among dogs living in the Plain zone and in rural areas was higher than the risk among dogs living in the Foothill zone and in urban areas in the areas of Iran that were studied, although the difference was not statistically significant. Future studies should emphasize larger populations of dogs in other parts of Iran, for molecular detection of E. canis and other Anaplasmataceae agents, as well as providing analysis on differences between risk factors.

\section{Acknowledgements}

The authors would like to express their gratitude to Dr. Hossein Azadi, of the Department of Geography, Ghent University, Belgium, for statistical data analysis; to N. Amininia, S. Ahmadzadeh, M. Taheri and F. Naderinejad, of the Department of Clinical Pathology, Faculty of Veterinary Medicine, University of Tehran, for their remarkable laboratory technical assistance; and to Silvana Marchioro, of the Biotechnology Department, Federal University of Pelotas, Brazil, for her kind help in translating the English abstract into Portuguese.

\section{References}

Aguirre E, Sainz A, Dunner S, Amusategui I, López L, Rodríguez-Franco F, et al. First isolation and molecular characterization of Ehrlichia canis in Spain. Vet Parasitol 2004; 125(3-4): 365-372. PMid:15482892. http:// dx.doi.org/10.1016/j.vetpar.2004.08.007

Akhtardanesh B, Ghanbarpour R, Blourizadeh H. Serological evidence of canine monocytic ehrlichiosis in Iran. Comp Clin Pathol 2010; 19(5): 469474. http://dx.doi.org/10.1007/s00580-009-0889-5
Avizeh R, Mosallanejad B, Razi Jalali MH, Alborzi AR. Seroprevalence of Ehrlichia canis in dogs referred to Veterinary Hospital of Shahid Chamran University of Ahvaz, Iran. Arch Razi Inst 2010; 65(1): 21-26.

Baneth G, Waner T, Koplah A, Weinstein S, Keysary A. Survey of Ehrlichia canis antibodies among dogs in Israel. Vet Rec 1996; 138(11): 257-259. PMid:8734508. http://dx.doi.org/10.1136/vr.138.11.257

Batmaz H, Nevo E, Waner T, Senturk S, Yilmaz Z, Harrus S. Seroprevalence of Ehrlichia canis antibodies among dogs in Turkey. Vet Rec 2001; 148(21): 665-666. PMid:11400989. http://dx.doi. org/10.1136/vr.148.21.665

Carlos RSA, Carvalho FS, Wenceslau AA, Almosny NRP, Albuquerque GR. Risk factors and clinical disorders of canine ehrlichiosis in the South of Bahia, Brazil. BrazJ Vet Parasitol 2011; 20(3): 210-214. http://dx.doi. org/10.1590/S1984-29612011000300006

Costa. LM, Rembeck K, Ribeiro MFB, Beelitz P, Pfister K, Passos LMF. Sero-prevalence and risk indicators for canine ehrlichiosis in three rural areas of Brazil. Vet J 2007; 174(3): 673-676. PMid:17204439. http:// dx.doi.org/10.1016/j.tvjl.2006.11.002

Dawson JE, Stallknecht DE, Howerth EW, Warner C, Biggie K, Davidson WR, et al. Susceptibility of White-tailed deer (Odocoileus virginianus) to infection with Ehrlichia chaffeensis, the etiologic agent of human ehrlichiosis. J Clin Microbiol 1994; 32(11): 2725-2728. PMid:7852563 PMCid:PMC264150.

Dawson JE, Biggie KL, Warner CK, Cookson K, Jenkins S, Levine JF, et al. Polymerase chain reaction evidence of Ehrlichia chaffeensis, an etiologic agent of human ehrlichiosis, in dogs from southeast Virginia. Am J Vet Res 1996; 57(8): 1175-1179. PMid:8836370.

Gaunt SD, Beall MJ, Stillman BA, Lorentzen L, Diniz PPV P, Chandrashekar R, et al. Experimental infection and co-infection of dogs with Anaplasma platys and Ehrlichia canis: hematologic, serologic and molecular findings. Parasit Vectors 2010; 3(1): 33. PMid:20377870 PMCid:PMC2859368. http://dx.doi.org/10.1186/1756-3305-3-33

Groves MG, Dennis GL, Amyx HL, Huxsoll DL. Transmission of Ehrlichia canis to dogs by ticks (Rhipicephalus sanguineus). Am J Vet Res 1975; 36(7): 937-940. PMid:1147359.

Hall TA. BioEdit: a user-friendly biological sequence alignment editor and analysis program for Windows 95/98/NT. Nucleic Acids Symp Ser 1999; 41: 95-98.

Huxsoll DL, Hildebrandt PK, Nims RM, Walker JS. Tropical canine pancytopenia. J Am Vet Med Assoc 1970; 157(11): 1627-1632. PMid:5530365.

Lim S, Irwin PJ, Lee S, Oh M, Ahn K, Myung B, et al. Comparison of selected canine vector-borne diseases between urban animal shelter and rural hunting dogs in Korea. Parasit Vectors 2010; 3(1):32. PMid:20377869 PMCid:PMC2860352. http://dx.doi.org/10.1186/1756-3305-3-32

Murphy GL, Ewing SA, Whitworth LC, Fox JC, Kocan AA. A molecular and serologic survey of Ehrlichia canis, E. chaffeensis, and E. ewingii in dogs and ticks from Oklahoma. Vet Parasitol 1998; 79(4): 325-329. http://dx.doi.org/10.1016/S0304-4017(98)00179-4

Neer TM, Breitschwerdt EB, Greene RT, Lappin MR. Consensus statement on ehrlichial disease of small animals from the infectious disease study group of the ACVIM. J Vet Intern Med 2002; 16(3): 309315. PMid:12041661.

Randolph SE. The impact of tick ecology on pathogen transmission dynamics. In: Bowman AS, Nuttall PA. Ticks: biology, disease, and control. 
New York: Cambridge University Press; 2008. p. 40-72. http://dx.doi. org/10.1017/CBO9780511551802.003

Rodriguez-Vivas RI, Albornoz REF, Bolio GME. Ehrlichia canis in dogs in Yucatan, Mexico: seroprevalence, prevalence of infection and associated factors. Vet Parasitol 2005; 127(1): 75-79. PMid:15619376. http://dx.doi.org/10.1016/j.vetpar.2004.08.022

Sainz A, Tesouro MA, Rodriguez F, Mayoral I, Mazzucchelli F. Seroprevalence of Ehrlichia canis infections in police dogs in Spain. Prev Vet Med 1995; 23(3-4): 179-182. http://dx.doi.org/10.1016/01675877(94)00440-T

Sonenshine DE. Ecology, behavior, and host-parasite interactions. In: Sonenshine DE. Biology of Ticks. Vol 2. New York: Oxford University Press; 1993. p. 3-104.

Solano-Gallego L, Trotta M, Razia L, Furlanello T, Caldin M. Molecular survey of Ehrlichia canis and Anaplasma phagocytophilum from blood of dogs in Italy. Ann N Y Acad Sci 2006; 1078: 515-518. PMid:17114768. http://dx.doi.org/10.1196/annals.1374.101
Thompson JD, Higgins DG, Gibson TJ. Clustal W: improving the sensitivity of progressive multiple sequence alignment through sequence weighting, position-specific gap penalties and weight matrix choice. Nucleic Acids Res 1994; 22(22): 4673-4680. PMid:7984417 PMCid:PMC308517. http://dx.doi.org/10.1093/nar/22.22.4673

Trapp SM, Dagnone AS, Vidotto O, Freire RL, Amude AM, de Morais HS. Seroepidemiology of canine babesiosis and ehrlichiosis in a hospital population. Vet Parasitol 2006; 140(3-4): 223-230. PMid:16647817. http://dx.doi.org/10.1016/j.vetpar.2006.03.030

Wall R Shearer D. Veterinary ectoparasites: biology, pathology and control. 2nd ed. Oxford, London: Blackwell Sciences Ltd Press; 2001.

Waner T, Harrus S, Jongejan F, Bark H, Keysary A, Cornelissen AWCA. Significance of serological testing for ehrlichial diseases in dogs with special emphasis on the diagnosis of canine monocytic ehrlichiosis caused by Ehrlichia canis. Vet Parasitol 2001; 95(1): 1-15. http://dx.doi. org/10.1016/S0304-4017(00)00407-6

Woody BJ, Hoskins JD. Ehrlichial diseases of dogs. Vet Clin North Am Small Anim Pract 1991; 21(1): 75-98. PMid:2014630. 